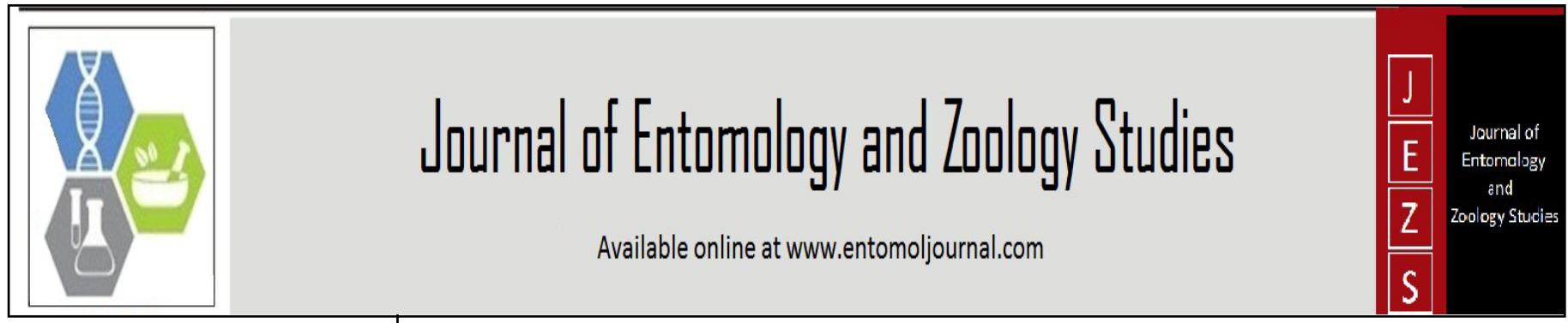

E-ISSN: 2320-7078

P-ISSN: 2349-6800

www.entomoljournal.com

JEZS 2021; 9(4): 32-39

(C) $2021 \mathrm{JEZS}$

Received: 13-05-2021

Accepted: 15-06-2021

Author's name and address given below.
Corresponding Author:

Ephraim Ezaka

a) Department of Parasitology

and Entomology, Nnamdi

Azikiwe University, Awka

Anambra State, Nigeria

b) Department of Medical laboratory Technology, College of Health Technology, Adamawa State, Nigeria

\section{Mosquito fauna of Anambra East LGA, Anambra state, Nigeria}

\author{
Chukwudi Egbuche, Ephraim Ezaka, Chiemelie Okwubanego, Ifeanyi \\ Omah, Victor Odoh, Chidera Obi, Tangkat Dashar, Johnpaul Egbobe, \\ Sandra Olisakwe, Tochukwu Okafor and Ifunanya Nwankwo
}

DOI: https://doi.org/10.22271/j.ento.2021.v9.i4a.8767

\begin{abstract}
A cross sectional study on mosquito fauna of Anambra East Local Government Area was carried out between June 2017 and August 2018. Pyrethrum knockdown and Human Landing Catch Collection methods were used to collect adult mosquitoes from indoor and outdoor locations respectively, in four randomly selected towns in the LGA. The mosquitoes were identified using standard taxonomic keys. A total of 681 adult mosquitoes were collected: 182 (26.7\%) in Aguleri, 135 (19.8\%) in Umuleri, 273 (40.1\%) in Igbariam and $91(13.4 \%)$ in Nando. Out of these, 551 (80.9\%) mosquitoes were collected from indoor location and 130 (19.1\%) mosquitoes from outdoor location (P < 0.05). Six (6) Genera of mosquito collected were: Anopheles (39.4\%), Aedes (3.7\%), Culex (37.9\%), Mansonia (18.4\%), Eretmapodite $(0.6 \%)$, and Coquilletidia $(0.15 \%)(\mathrm{P}<0.05)$. Only Culex mosquitoes showed significant difference in indoor abundance, $43.6 \%$ and outdoor abundance $13.8 \%(\mathrm{P}<0.05)$. Sixteen species of mosquitoes were identified. The most abundant species of mosquito was $C x$. quinquefasciatus, with $35.9 \%$ abundance and the least were Coquellettidia species and $C x$. annuloris, $0.15 \%$ abundance each (P $<0.05$ ). The most abundant Species of mosquito in indoor location was Anopheles gambiae s. 1, with 42.3\% abundance and the least were Ae. albopictus and Cx. annuloris, with $0.2 \%$ abundance each $(\mathrm{P}<$ 0.05). The most abundant species of mosquito in the outdoor locations was Mansonia uniformis, with $34.6 \%$ abundance and the least were An. funestus and Coquellettidia, with $0.80 \%$ abundance $(\mathrm{P}<0.05)$. The presence of the different mosquito species found in this study area is of great medical importance. Most of the species are already known vectors of disease pathogens. Therefore, personal protection, provision of adequate mosquito management options, regular surveillance, and public health sensitizations are hereby recommended.
\end{abstract}

Keywords: mosquito fauna, indoor, outdoor, Anambra east Lga, Nigeria

\section{Introduction}

Mosquitoes are arthropods that belong to the Class Insecta, Order Diptera, and Family Culicidae. Mosquitoes have world-wide distribution and they inhabit both aquatic and terrestrial habitats ${ }^{[1]}$. Nevertheless, natural factors like temperature, humidity, and rainfall can have impact on the spatial and temporal distribution as well as the overall abundance of mosquitoes ${ }^{[2]}$. In addition, temperature and concentration of some heavy metals may have effect on the survival of immature stages of mosquitoes in their breeding habitats [3]. Furthermore, environmental changes due to human activities greatly influence the distribution and survival of many mosquito species ${ }^{[3,4]}$.

The female mosquitoes are known bloodsuckers that require blood meal for the development of their eggs and also for laying viable eggs ${ }^{[5]}$. Thus blood meal is an integral aspect of their gonotrophic cycle. The mosquito gonotrophic cycle can be as short as two days but could take over a week, depending on temperature ${ }^{[6]}$. After feeding, some part of the gonotrophic cycle of mosquitoes is spent resting. Mosquito resting behavior could be endophilic or exophilic. An endophilic mosquito rests indoors, inside a human dwelling, during the period between the end of blood-feeding and the onset of searching for an oviposition site ${ }^{[7]}$. Indoor-biting mosquitoes frequently rest on a wall, under furniture, or on hanging clothes. The most important vectors of human diseases are those that show a close association with man and prefer man to animals as a source of blood meal ${ }^{[8]}$. In the course of their bite, they could transmit disease pathogens. The spread of diseases transmitted by mosquitoes is encouraged by ecological factors such as 
rapid urbanization, excessive deforestation, and insecticide resistance by mosquitoes among others. This is as a result more breeding sites created, high proliferation rate of mosquitoes and availability of infected and susceptible hosts; thereby enhancing the transmission of mosquito-borne diseases especially malaria. Having this in mind, Anambra East LGA falls in the category of locations in Anambra State, experiencing rapid urbanization and other developmental changes, thereby exposing the inhabitants to risks of mosquito-borne infections. Attractions to Anambra East Local Government Area include: large scale commercial agriculture, availability of unexplored oil deposits and construction of Cargo airport and houses. These have led to a massive influx of people into Anambra East LGA. Hence there is a need to know the mosquito fauna of the LGA as a guide to determining the risk of mosquito borne diseases in the area.

\section{Materials and Methods \\ Study area}

The study was carried out in Anambra East Local Government Area of Anambra State. The Local Government Area comprised: Aguleri, Nando, Igbariam, Umuoba Anam, Umueri, and Nsugbe towns. Anambra East Local Government Area is located in the tropical rainforest region of Nigeria that has two marked seasons: the dry (November to March) and wet seasons (April to October). According to the National Population Commission (2006), Anambra East Local Government Area had a population of about one hundred and fifty-two thousand, one hundred and forty-nine persons $(152,149)$. Recently there is a huge influx of people from different parts of Nigeria and beyond into Anambra East Local Government Area as a result of the massive construction activities and opening up of unoccupied areas. Predominantly, the inhabitants are farmers, traders, civil servants, and students. The unique arable land, valleys, and deep sparking springs made the Local Government Area rich in various agricultural produce such as yams, cassava, maize, potato, rice and vegetables. By religion, the inhabitants of Anambra East LGA practice Christianity or African Traditional Religion which are shown by the churches and shrines that are present. The LGA has two large bodies of water: Ezu and Omambala. Also, water collections were seen in some environments littered with discarded containers or ditches which can serve as good breeding sites for the mosquito vectors. The construction activities in the LGA also provided additional breeding sites for mosquitoes.

\section{Ethical consideration}

A letter of introduction was presented to the traditional ruler and opinion leaders in the study area during advocacy visits. Verbal consent of the Heads of the various houses whose compounds and rooms were used for Pyrethrum Knockdown Collection (PKC) and Human Landing Catch (HLC) were obtained. Also Ethical approval for the study was obtained from Chukwuemeka Odumegwu Ojukwu University Teaching Hospital (COOUTH) Amaku Awka.

\section{Study design and sampling technique}

The research was a cross-sectional study carried out between June 2017 and August 2018. The study included the collection of adult mosquitoes from indoor and outdoor locations. The sampling universe, Anambra East LGA was first divided into strata, such that each of the four randomly selected towns in the LGA constitutes a stratum. In each stratum, households, considered as sampling units were selected using a systematic sampling method. Houses, where people slept the previous night, were selected for the pyrethrum knockdown collection (PKC). Human Landing Catch (HLC) was carried out around the selected houses as well as in areas where there are no houses.

\section{Indoor collection of adult mosquitoes}

This was achieved using Pyrethrum knockdown collection Method. The collections were made in the early hours, between $6.30 \mathrm{am}$ and $8.00 \mathrm{am}$. Rooms where at least one person slept the previous night, were chosen for the exercise. Pyrethroid, Raid ${ }^{\circledR}$ was used for the collection, following the standard operation procedure by ${ }^{[9]}$. Adult mosquitoes collected were transported to the Laboratory unit of the Department of Parasitology and Entomology, Nnamdi Azikiwe University Awka Nigeria for proper identification.

\section{Outdoor collection of adult mosquitoes}

These were collected on human volunteers using Human Landing Catch (HLC) between 5:00 pm to 8:00 pm following the procedures of ${ }^{[10,11]}$. The body extremities were exposed to the landing mosquitoes that had come for their blood meal. Using torchlight and test tubes, settled mosquitoes were collected and stoppered with cotton wool. All the collection were then sorted out, and transported to the Laboratory unit of the Department of Parasitology and Entomology, Nnamdi Azikiwe University Awka Nigeria for proper identification.

\section{Identification of the collected mosquitoes}

The mosquitoes were identified using the gross morphology of the species: external morphology of the head, mouthparts, antenna, proboscis, patches of pale and black scales on the wings and legs, and the terminal abdominal segments ${ }^{[12]}$.

\section{Data summary and statistical analysis}

Data obtained from the study was summarized using tables. Test of statistical significance at 5\% level was done using SPSS version 25.0. Paired T test was used to compare the indoor and outdoor abundance of mosquitoes in the study area. Analysis of Variance (ANOVA) was used to compare the abundance of different mosquito genera and species in the study area.

\section{Results}

A total of 681 adult mosquitoes were collected from the study area. Table 1 showed that 182 (26.7\%), 135 (19.8\%), 273 (40.1\%), and 91 (13.4\%) of the mosquitoes were collected in Aguleri, Umueri, Igbariam, and Nando respectively. In the indoor locations, 551 mosquitoes were collected whereas, in the outdoor locations, 130 mosquitoes were collected. The indoor and outdoor abundance of mosquitoes in the towns within the study area are equally shown in Table 1 . The difference in the overall abundance of mosquitoes in indoor and outdoor locations was statistically significant $(\mathrm{P}=0.01)$.

Table 1: Overall abundance of adult mosquitoes in the study areas

\begin{tabular}{|c|c|c|c|}
\hline \multirow{2}{*}{ Site } & \multicolumn{3}{|c|}{ Mosquito abundance (\%) } \\
\cline { 2 - 4 } & $\begin{array}{c}\text { Indoor } \\
\text { Collection (\%) }\end{array}$ & $\begin{array}{c}\text { Outdoor collection } \\
\text { (\%) }\end{array}$ & Total (\%) \\
\hline Aguleri & $141(25.6)$ & $41(31.5)$ & $182(26.7)$ \\
\hline Umueri & $115(20.9)$ & $20(15.4)$ & $135(19.8)$ \\
\hline Igbariam & $214(38.8)$ & $59(45.4)$ & $273(40.1)$ \\
\hline Nando & $81(14.7)$ & $10(7.7)$ & $91(13.4)$ \\
\hline Total & $551(100)$ & $130(100)$ & $681(100)$ \\
\hline Mean \pm SE & $137.8 \pm 28.2$ & $32.5 \pm 10.9$ & - \\
\hline
\end{tabular}


The 681 adult mosquitoes collected included 6 different Genera and 15 different species of mosquitoes (Table 2). There were 5 Genera and 10 species overlaps between indoor and outdoor mosquito collections. The indoor and outdoor counts of the number of Genera and Species of mosquitoes collected are shown in Table 2 below.

Table 2: Mosquito genera and species collected from the study area

\begin{tabular}{|c|c|c|c|}
\hline $\begin{array}{c}\text { Collection } \\
\text { place }\end{array}$ & $\begin{array}{c}\text { No. of } \\
\text { mosquitoes } \\
\text { collected }\end{array}$ & $\begin{array}{c}\text { No. of mosquito } \\
\text { genera present }\end{array}$ & $\begin{array}{c}\text { No. of mosquito } \\
\text { species present }\end{array}$ \\
\hline Indoor & 551 & 5 Genera & 12 Species \\
\hline Outdoor & 130 & 6 Genera & 14 Species \\
\hline Indoor + outdoor & 681 & 6 Genera & 16 Species \\
\hline
\end{tabular}

The six different Genera of mosquitoes collected from the study area are shown in Figure 1. The most abundant Genera of mosquito was Anopheles, with a percentage abundance of $39.4 \%$. The least abundant Genera of mosquito was Coquellettidia, with a percentage abundance of $0.15 \%$. There was a significant difference in the percentage abundance of the different mosquito genera collected from the study area ( $\mathrm{P}$ $=0.01$ ).

The distribution and percentage abundance of the different Genera of mosquitoes in indoor and outdoor locations are shown in Figure 2. The most abundant Genera of mosquito in indoor location was Anopheles, with a percentage abundance of $46.3 \%$. The least abundant Genera of mosquito was Eretmapodite, with a percentage abundance of $0.4 \%$. Coquellettidia was absent in the indoor locations. There was a significant difference in the percentage abundance of the different mosquito genera collected indoors from the study area $(\mathrm{P}=0.015)$.

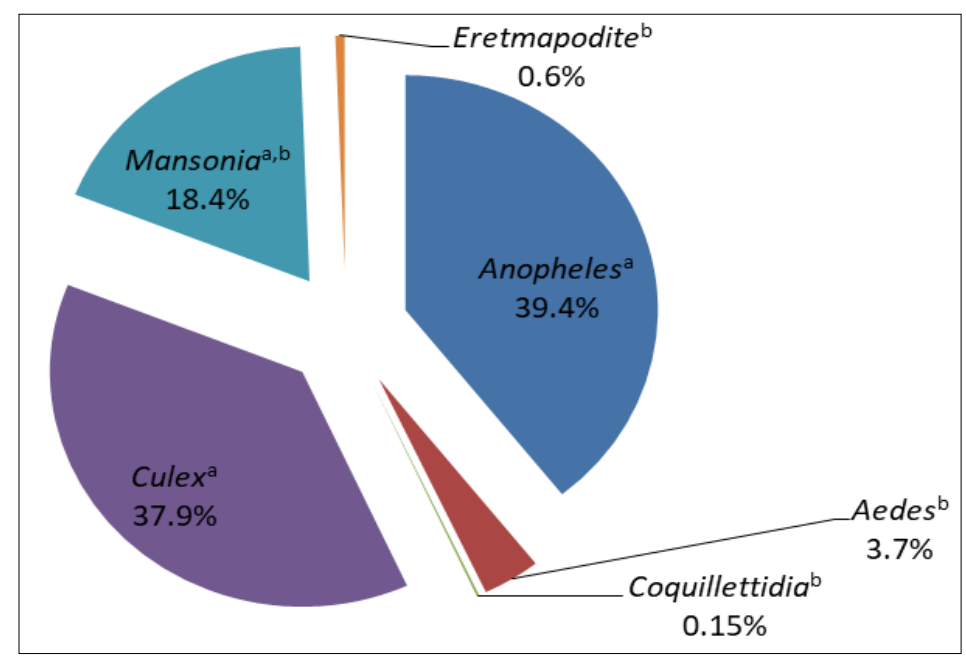

Fig 1: Different genera of mosquitoes collected from the study area

The most abundant Genera of mosquito in outdoor location was Mansonia, with a percentage abundance of $57.7 \%$. The least abundant Genera of mosquito was Coquellettidia, with a percentage abundance of $0.80 \%$. However, there was no significant difference in the percentage abundance of the different mosquito genera collected outdoors from the study area $(\mathrm{P}=0.069)$.

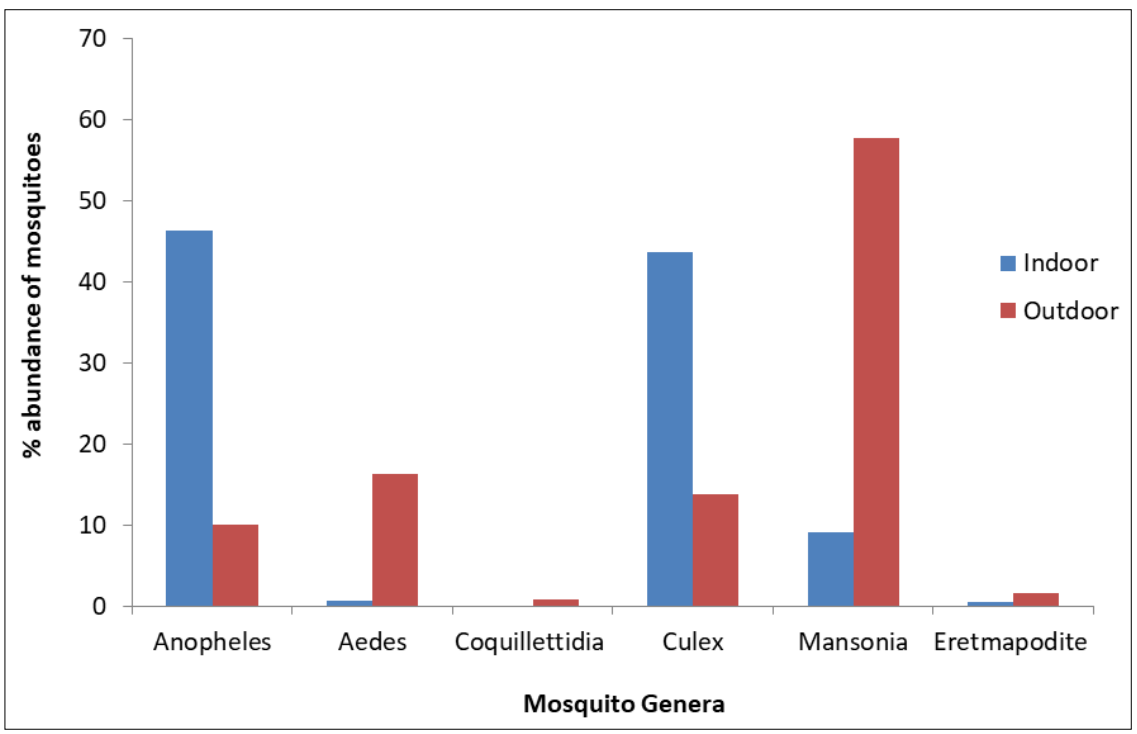

Fig 2: Distribution and percentage abundance of mosquito genera in indoor and outdoor locations

Anopheles mosquitoes constituted $46.3 \%$ of indoor collections and $10.0 \%$ of outdoor collections $(\mathrm{P}=0.106)$. Aedes mosquitoes constituted $0.70 \%$ of indoor collections and $16.0 \%$ of outdoor collections $(\mathrm{P}=0.056)$. Coquellettidia was 
only collected outdoors with percentage abundance of $0.80 \%$. Culex mosquitoes constituted $43.6 \%$ of indoor collections and $13.8 \%$ of outdoor collections $(\mathrm{P}=0.002)$. Mansonia mosquitoes constituted $9.1 \%$ of indoor collections and $57.7 \%$ of outdoor collections ( $\mathrm{P}=0.582)$. Chrysogaster mosquitoes constituted $0.40 \%$ of indoor collections and $1.52 \%$ of outdoor collections $(\mathrm{P}=1.000)$.

The sixteen different Species of mosquitoes collected from the study area are shown in Figure 3. The most abundant species of mosquito was $C x$. quinquefasciatus, with a percentage abundance of $35.9 \%$. The least abundant Species of mosquito were Coquellettidia species and Culex annuloris, with a percentage abundance of $0.15 \%$ each. The percentage abundance of other mosquito species were $35.4 \%$ for $A n$. gambiae s.s., $0.9 \%$ for An. nili, $1.8 \%$ for An. funestus, $1.3 \%$ for An. moucheti, $0.7 \%$ for Ae. aegypti, $1.03 \%$ for Ae. albopictus, $0.3 \%$ Ae. africanus, $1.3 \%$ for Ae. circumluteolus, $0.3 \%$ for Ae. taylori, $1.8 \%$ for $C x$. tigripes, $11.5 \%$ for Mansonia uniformis, 6.9\% for Mansonia africanus and $0.6 \%$ for Eretmapodite chrysogaster. There was a significant difference in the percentage abundance of the different mosquito species collected from the study area $(P=0.000)$.

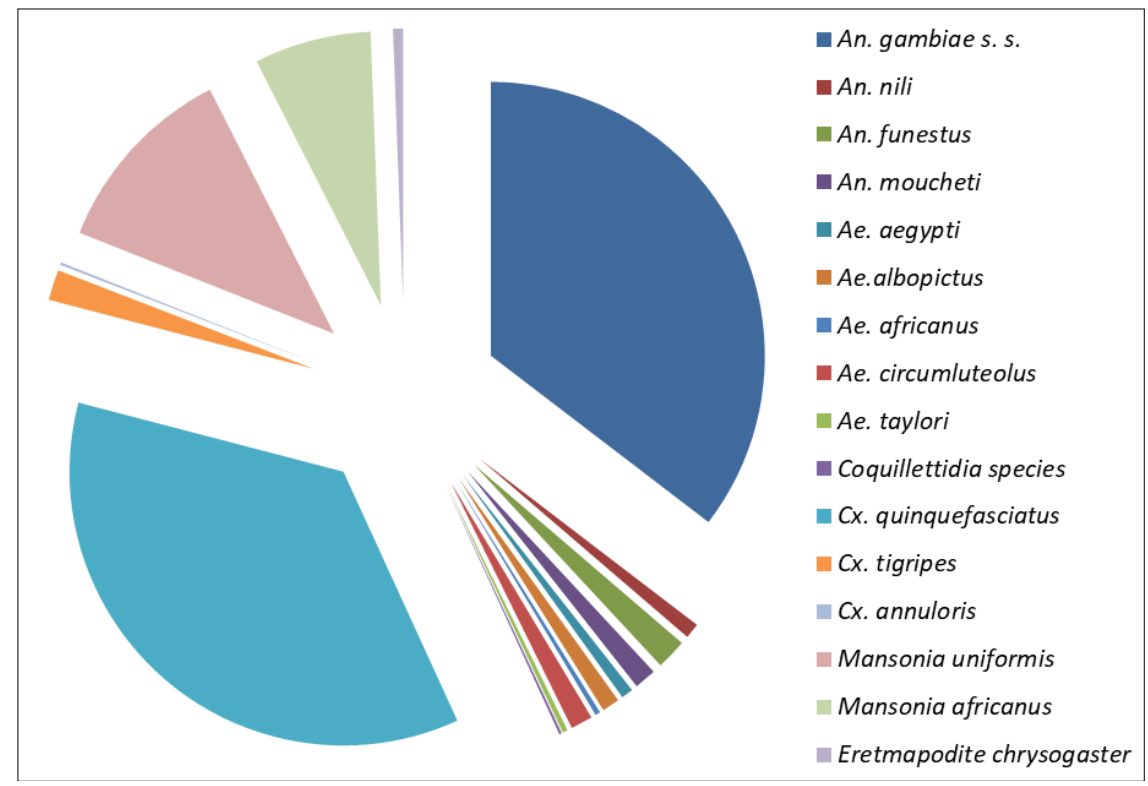

Fig 3: Different species of mosquitoes collected from the study area

The distribution and percentage abundance of the different species of mosquitoes in indoor and outdoor locations are shown in Figure 4. The most abundant Species of mosquito in indoor location was Anopheles gambiae s.l, with a percentage abundance of $42.3 \%$. The least abundant species of mosquito were Ae. albopictus and Cx. annuloris, with a percentage abundance of $0.2 \%$ each. Coquellettidia species, Ae. aegypti, Ae. africanus and Ae. taylori were absent in the indoor locations. The abundance of other species indoors were: $0.7 \%$ for An. nili, 2.0\% for An. funestus, $1.3 \%$ for An. moucheti, $0.5 \%$ for Ae. circumluteolus, $41.2 \%$ for $C x$. quinquefasciatus, $2.2 \%$ for $C x$. tigripes, $6.0 \%$ for Mansonia uniformis, 3.1\% for Mansonia africanus and $0.4 \%$ for Eretmapodite chrysogaster. There was a significant difference in the percentage abundance of the different mosquito genera collected indoors from the study area $(\mathrm{P}=0.000)$.

The most abundant species of mosquito in the outdoor locations was Mansonia uniformis, with a percentage abundance of $34.6 \%$. The least abundant species of mosquito were An. funestus and Coquellettidia, with a percentage abundance of $0.80 \%$. Cx. tigripes and $C x$. annuloris were absent in the outdoor locations. The abundance of other species indoors were: $6.2 \%$ for An. gambiae s. l., 1.5\% for An. nili, $1.5 \%$ for An. moucheti, 3.8\% for Ae. aegypti, $4.6 \%$ for Ae. albopictus, $1.5 \%$ for Ae. africanus, $4.6 \%$ for Ae. circumluteolus, $1.5 \%$ for Ae. taylori, $13.8 \%$ for $C x$. quinquefasciatus, 34.6\% for Mansonia uniformis, $23.1 \%$ for Mansonia africanus and 1.5\% for Eretmapodite chrysogaster. However, there was no significant difference in the percentage abundance of the different mosquito genera collected outdoors from the study area $(\mathrm{P}=0.054)$.

An. gambiae s.l. constituted $42.3 \%$ of indoor collections and $6.2 \%$ of outdoor collections $(\mathrm{P}=0.136)$. An. nili constituted $0.7 \%$ of indoor collections and $1.5 \%$ of outdoor collections (P $=0.585)$. An. funestus constituted $2.0 \%$ of indoor collections and $0.8 \%$ of outdoor collections $(\mathrm{P}=0.07)$. An. moucheti constituted $1.3 \%$ of indoor collections and $1.5 \%$ of outdoor collections $(\mathrm{P}=0.067)$. Ae. aegypti constituted $0.0 \%$ of indoor collections and $3.8 \%$ of outdoor collections ( $\mathrm{P}=$ 0.002). Ae. albopictus constituted $0.2 \%$ of indoor collections and $4.6 \%$ of outdoor collections $(\mathrm{P}=0.121)$. Ae. africanus constituted $0.0 \%$ of indoor collections and $1.5 \%$ of outdoor collections $(\mathrm{P}=0.356)$. Ae. circumluteolus constituted $0.5 \%$ of indoor collections and $4.6 \%$ of outdoor collections ( $\mathrm{P}=$ 0.560). Coquellettidia was only collected outdoors with percentage abundance of $0.80 \% \quad(\mathrm{P}=0.356)$. Cx. quinquefasciatus constituted $41.2 \%$ of indoor collections and $13.8 \%$ of outdoor collections $(\mathrm{P}=0.356)$. $C x$. annuloris constituted $0.2 \%$ of indoor collections and $0.0 \%$ of outdoor collections $(\mathrm{P}=0.168)$. $C x$. tigripes constituted $2.2 \%$ of indoor collections and $0.0 \%$ of outdoor collections $(\mathrm{P}=$ 0.001). Mansonia uniformis constituted $6.0 \%$ of indoor collections and $34.6 \%$ of outdoor collections $(P=0.356)$. Mansonia africanus constituted $3.1 \%$ of indoor collections and $23.1 \%$ of outdoor collections $(\mathrm{P}=0.686)$. Chrysogaster mosquitoes constituted $0.40 \%$ of indoor collections and $1.5 \%$ of outdoor collections $(\mathrm{P}=0.464)$. 


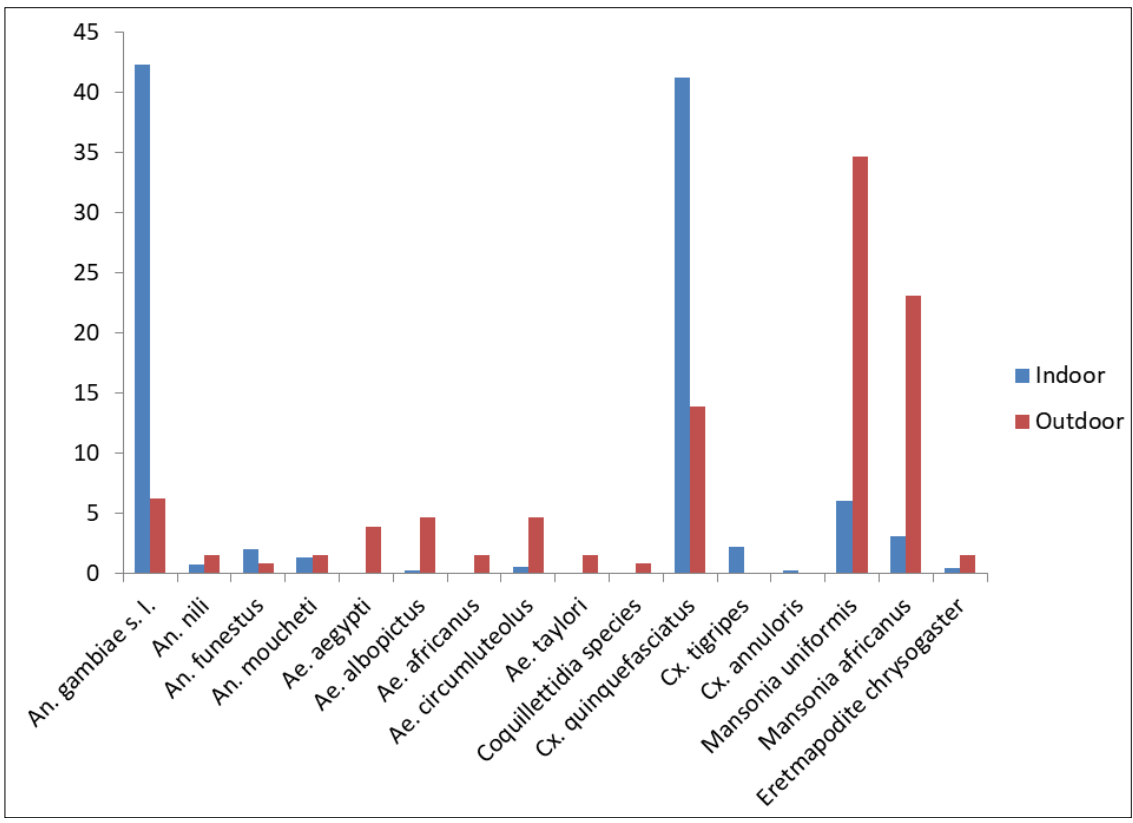

Fig 4: Distribution and percentage abundance of mosquito genera in indoor and outdoor locations

\section{Discussion}

A total of 681 adult mosquitoes were collected and identified in the study area, between June 2017 and August 2018. Even though the mosquito population is low considering the study duration, it could be due to the housing conditions (the absence of ceilings, window nets, or door nets which allow blood-fed mosquitoes to escape before or during indoor collection) in the study area and inefficiency of HLC as a collection method; it still affirms the fact that mosquitoes are found virtually everywhere and are part of the ecosystem. These mosquitoes were collected both inside and outside the house, showing that they are found in close proximity to human dwellings when they leave their breeding habitats to search for blood meal. The significant difference in the overall abundance of mosquitoes in indoor and outdoor locations could be attributed to time of collection as well as the techniques used for the collection. Our indoor collection was done in the morning hours when mosquitoes were still trapped/resting indoors after taking blood meals during the night hours when people are at sleep. During that morning period, a larger population of them can easily be caught using PKC method. Of course, PKC method is expected to be more efficient in mosquito collection than HLC ${ }^{[13]}$, even though their suitability for indoor and outdoor use differs. Inefficiency of the human volunteers and windy conditions of the environment could also be the reason for lower number of adult mosquitoes collected in outdoor location.

Highest abundance of mosquitoes was recorded in Igbariam than in Aguleri, Umueri and Nando. This could be attributed to inconsistency in the efficiency of mosquito collectors, unequal distribution of breeding habitats of mosquitoes, and differences in the management of the environment by the inhabitants of the areas. All these accounted for the variation in mosquito abundance in the four studied locations [14] observed that mosquito distribution and abundance are related to population, land use, and human activities. The few mosquitoes collected at Nando could be attributed to heavy rainfall and windy weather on the days of collection. This suggests that outdoor biting mosquito populations can be low on rainy and windy days.

This study revealed six ${ }^{[6]}$ mosquito genera: Anopheles, Aedes,
Culex, Coquillettidia, Mansonia and Eretmapodite. This finding is similar to the work of ${ }^{[4]}$, where he reported the presence of five (5) mosquito genera: Mansonia, Aedes, Culex, Anopheles, and Eretmapodite in Ogun state, midwestern Nigeria. There was a significant difference in the percentage abundance of the different mosquito genera collected from the study area. This implies that the complex ecosystem in the study area can support the continual breeding and survival of one or more Genera of mosquito than others as also observed by ${ }^{[15]}$. The variations in the abundance of different mosquito Genera can be attributed to the difference in their breeding habitat requirements and proximity to human dwellings.

In outdoor location, there was no significant difference in the abundance of different mosquito Genera collected from the study area. Nevertheless, Mansonia was the most abundant Genera collected outdoor. The most abundant Genera in indoor location was Anopheles mosquito. This could be one of the adaptations that enhance their efficiency in the transmission of malaria parasites and other pathogens transmissible by Anopheles mosquitoes. Considering all the Genera of mosquitoes collected, only Culex mosquitoes showed significantly higher abundance indoors than outdoors, even though [16] opined that adult mosquitoes are found around the areas where humans are aggregated. It points to the fact that Culex mosquitoes now tends to be highly endophagic and endophilic.

Among the mosquito Genera, Sixteen (16) mosquito species were identified. These comprised Anopheles gambiae s. l., Anopheles nili, Anopheles funestus, Anopheles moucheti, Aedes aegypti, Aedes albopictus, Aedes africanus, Aedes circumluteolus, Aedes taylori, Coquillettidia species, Culex quinquefasciatus, Culex tigripes, Culex annuloris, Mansonia uniformis, Mansonia africanus, and Eretmapodite chrysogaster. This shows that Anambra East Local Government Area has favorable breeding habitats and/or sites for different species of mosquitoes. ${ }^{[17]}$ had earlier reported the presence of eight (8) mosquito species: Ae. aegypti, Ae. albopictus, Ae. Circumlutoelus, An. gambiae, An. funestus, An. moucheti, $C x$. quinquefasciatus, $C x$. tigripes in open and closed larval habitats in Aguleri, Anambra East Local 
Government Area of Anambra State. In Benue state, [3] reported the presence of $C x$. quinquifasciatus, An. gambiae s. s., An. funestus, An. coustani, An. moucheti, Mansonia uniformis, Mansonia Africanus, Ae. albopictus and Ae aegypti. Also, ${ }^{3,}{ }^{18]}$, reported $C x$. quinquefasciatus, Ae. albopictus, Ae. aegypti, Ae. africanus, Cx. tigripes, An. funestus and An. gambiae in different refuse dumps within Enugu Municipal and four Communities in Awka-South Local Government Area of Anambra State, Nigeria respectively. Another researcher [19] reported $C x$. quinquefasciatus Coquillettidia metallica, Ae. aegypti, Ae. africanus, Ae. vittatus, and Eretmapodite chrysogaster in a zoological garden at Jos plateau. However, Eretmapodite quinquevittatus, Eretmapodite inornatus, and Aedes luteocephalus, which he also reported were not collected in this present study. This could be attributed to the fact that the researcher sampled for both the larvae and adult and equally worked in a zoological garden, suggesting that some of the mosquitoes collected were more zoophargic than anthropophargic (prefers animal blood to human blood). In Ogun state, mid-Western Nigeria ${ }^{[4]}$, reported ten species comprising Mansonia africana, Mansonia uniformis, Cx. quinquefasciatus, Ae. aegypti, Ae. albopictus, Ae. vittatus, Cx. tigripes, An. gambiae s. l., An. funestus and Eretmapodite chrysogaster, however, only Ae. vittatus was not found in Anambra East Local Government Area probably because of the difference in the geographical areas and micro-ecological conditions. This suggests that variation in species composition can exist across different geographical areas.

This study revealed that mosquito abundance in the study location is dominated by $C x$. quinquefasciatus, and this is similar to the report of Ezihe et al., (2020) ${ }^{[2]}$ in a different study area. This could be due to the limited basic infrastructure, lack of comprehensive water and waste management system as well as poor sanitary conditions that characterize most populated rural areas like Anambra East LGA. These conditions enhance the creation of favourable breeding habitats for Culex mosquitoes. This also aligned with the findings of [20] and [21] who reported a higher abundance of $C x$. quinquefasciatus compared to other species collected from Oba, Anambra State, South-East and Ibadan, Midwestern Nigeria respectively. However, it contrasted with a finding from North Central Nigeria by ${ }^{[22]}$, where Anopheles species were the most abundant mosquito species collected. This difference in the findings could be attributed to the micro ecological conditions, sampling universe, techniques used for the mosquito collection, life cycle stage collected, time of collection and duration of the study.

There was variation in the abundance of different mosquito species collected indoors only. An. gambiae s. l, featured prominently with the highest abundance. This agreed with the work of ${ }^{[23]}$, where he reported An. gambiae as the mosquito with the highest percentage abundance of the indoor biting and resting mosquitoes collected in Nnamdi Azikiwe University school hostels. The surrounding rivers and agricultural activities in the study area might have favored the build-up of their population (Egbuche et al., 2016) ${ }^{[2]}$ since they are known to breed in clean water. Also, the early hours favoured the collection of more An. gambiae s. l. than other mosquito species because of the variations in the peak biting and resting time of mosquitoes. It is possible that day time collection could have increased the populations of Aedes mosquitoes [17]. In outdoor collections alone, Mansonia uniformis dominated the outdoor population of mosquitoes and could be of great economic importance. Their presence shows that their breeding habitats are found and are possibly in the natural environment other than domestic containers.

The entire mosquito species collected showed no significant difference between their indoor abundance and outdoor abundance, with the exception of Ae. aegypti that recorded higher outdoor abundance and $C x$. tigripes that recorded higher indoor abundance. The indoor and outdoor distribution of these mosquitoes could be a matter of chance. This is because these mosquitoes have their breeding sites located in different parts of the environment and on emergence, the adults fly away to search for blood meals and resting places. Thus there is tendency of collecting them around human dwellings and/or rooms. This explains why majority of the mosquito species exhibit both exophargic and endophargic tendencies.

The presence of the different mosquito species found in this study is of great importance in the study area. This is because the biting activities of adult mosquitoes have resulted in nuisance and transmission of disease pathogens. For instance, An. gambiae is a proven vector of malaria and lymphatic filariasis in Nigeria [21]. Cx. quinquefasciatus has been reported to be infective with Wucheraria bancrofti ${ }^{[24]}$ among the Ezza group in Ebonyi state, Southeast, Nigeria, which is also a neighboring state. In Nigeria, Eretmapodite species have not been known to be involved in disease transmission; however Eretmapodites chrysogaster is known to be capable of transmitting yellow fever (Gillet, 1972; Service, 1980) [12, ${ }^{25]}$. Although this situation has not been reported in Nigeria, a close watch is required on this mosquito as it feeds on or is attracted to men. The agent of febrile rickettsiosis, Rickettsia felis, has been identified in mosquitoes ${ }^{[26]}$ and has also been shown to be potentially transmitted by Anopheles mosquitoes in laboratory experiments [27]. An. funestus can transmit several arboviruses and has equally been incriminated as a vector of malaria [28], lymphatic filariasis [29], and chikungunya virus ${ }^{[30]}$. Aedes mosquitoes are the dominant vectors of major arboviruses that infect humans and animals worldwide ${ }^{[31]}$. In 1991, Aedes spp was incriminated in an outbreak of yellow fever in Delta state, which is a neighboring state ${ }^{[32]}$. Ae. aegypti is the principal vector of viral infections such as dengue fever virus, encephalitis virus, hemorrhagic fever virus, chikungunya, Rift Valley viruses. ${ }^{\text {[3] }}$ reported that Aedes aegypti and Ae. albopictus are the major vectors of the dengue virus (DENV). Ae. aegypti which transmits Yellow fever ${ }^{[34]}$ is also the only domestic vector of this virus in West Africa ${ }^{[31]}$. Aedes aegypti is also considered to be the primary vector associated with ZIKV outbreaks ${ }^{[35] .}$ Other species collected which have not been implicated in diseases transmission may have potentials in the spread of some infectious diseases of human. Thus there is need for effective implementation of mosquito control strategies so as to prevent the occurrence of mosquito borne disease epidemics.

\section{References}

1. Goselle ON, Amobi LO, Ojile JO, David A et al. Abundance of Mosquitoes larvae in various microhabitats and the concern for invasion of human community. Int $\mathrm{J}$ Mosq Res 2017;4(4):119-125

2. Ezihe EK, Egbuche CM, Ukonze CB, Nwangwu UC, Onwude CO, Amakiri PC et al. The Impact of Human and Socio-cultural behavior on Outdoor malaria transmission in a rural community of Nigeria: The 
Nyumagbagh Experience. New York Sci J 2020;13(12): 86-99.

3. Ezihe KC, Egbuche CM, Job U, Friday MC, Anumba JU, Nwankwo EN et al. Mosquito Species Associated with Refuse Dumps within Enugu Municipal, Enugu State, Nigeria. J Mosq Res 2017;7(6):1-5.

4. Adeleke MA, Mafiana CF, Idowu AB, Adekunle MF, Sam-Wobo SO. Mosquito larval habitats and public health implications in Abeokuta, Ogun State, Nigeria. Tanzan J Health Res 2008.

5. Bockarie MJ, Service MW, Barnish G, Momoh W, Salia F. The effect of woodsmoke on the feeding and resting behaviour of Anopheles gambiae s.s. Acta Trop 1994.

6. Afrane YA, Lawson BW, Githeko AK, Yan G. Effects of microclimatic changes caused by land use and land cover on duration of gonotrophic cycles of Anopheles gambiae (Diptera: Culicidae) in western Kenya highlands. J Med Entomol 2005.

7. Pates H, Curtis C. Mosquito Behavior and Vector Control. Annu Rev Entomol [Internet] 2005;50(1):53-70. Available

from:http://www.annualreviews.org/doi/10.1146/annurev .ento.50.071803.130439

8. Ward RD. Medical Entomology for Students 3rd Edn. By M.W. Service, P285. Cambridge University Press UK 2004. ISBN 052154775X. £27.00. (US \$48.00). Parasitology [Internet] 2005;131(3):436-436. Available from:

https://www.cambridge.org/core/product/identifier/S0031 182005228585/type/journal_article

9. Ii P. Malaria entomology and vector control Trial Edition. World Heal Organ [Internet] 2003. Available from:

file://C:/Users/css/Desktop/Legwork/WHO_CDS_CPE_ SMT_2002.18_Rev.1_PartI.pdf

10. Onyido AE, Agbata VO, Umeanaeto PU, Obiukwu MOAE. Malaria burden and vector abundance in a suburban community in the rainforest zone of Nigeria. Niger J Microbiol 2010;24(1):2224-30.

11. Egbuche CM, Onyido AE, Umeanaeto PU, Omah IF, Ukonze CB, Okeke JJ et al. Anopheles species composition and some climatic factors that influence their survival and population abundance in Anambra East LGA, Anambra State, Nigeria. Niger J Parasitol 2020;41(2):240-250.

12. Gillett JD, Smith JG. Common African mosquitos and their medical importance. London: Heinemann Medical 1972.

13. Sikaala CH, Killeen GF, Chanda J, Chinula D, Miller JM, Russell TL et al. Evaluation of alternative mosquito sampling methods for malaria vectors in Lowland South East Zambia. Parasit Vectors [Internet] 2013;6(1):91. Available

from:https://parasitesandvectors.biomedcentral.com/articl es/10.1186/1756-3305-6-91

14. Simon-Oke I, Olofintoye L. The effect of climatic factors on the distribution and Aaundance of mosquito vectors in Ekiti State. J Biol Agric Healthc 2015;5(9):142-7.

15. Adeleke MA, Mafiana CF, Idowu AB, Sam-Wobo SO, Idowu OA. Population dynamics of indoor sampled mosquitoes and their implication in disease transmission in Abeokuta, south-western Nigeria. J Vector Borne Dis [Internet] 2010;47(1):33-8. Available from: http://www.ncbi.nlm.nih.gov/pubmed/20231771
16. Smith DL, Dushoff J, Snow RW, Hay SI. The entomological inoculation rate and Plasmodium falciparum infection in African children. Nature [Internet] 2005;438(7067):492-5. Available from: http://www.nature.com/articles/nature04024

17. Egbuche CM, Ezihe CK, Aribodor DN, Ukonze CB. Survey of mosquitoes in open and closed larval habitats in Aguleri, Anambra East Local Government Area of Anambra State, South Eastern Nigeria. J Mosq Res 2016;6(17):1-5.

18. Aribodor DN, Aribodor OB, Eneanya CI, Onyido AE. Survey of Open Larval Habitats of Mosquitoes in Four Communities in Awka South Local Government Area, Anambra State, Nigeria. J Chem Inf Model 2013;53(9):1689-99.

19. Onyido A, Ozumba N, Ezike V, Chukwuekezie O, Nwosu E, Nwaorgu O et al. Mosquito fauna of a tropical museum and zoological garden complex. Anim Res Int [Internet] 2009;5(2). Available from: http://www.ajol.info/index.php/ari/article/view/48746

20. Okonkwo NJ, Obiechina IO, Ugha CN, Irikannu KC, Obianumba SN, Okoye-Uzochukwu CI et al. Mosquito species compositions in Oba, Idemili South Local Government Area of Anambra state 2014;6(8):51-6. Available from http://www.sciencepub.net/researcher/research0608/007_ 26522research060814_51_56.pdf

21. Okorie PN, McKenzie FE, Ademowo OG, Bockarie M, Kelly-Hope L. Nigeria Anopheles Vector Database: An Overview of 100 Years' Research. Mores CN, editor. PLoS One [Internet] 2011;6(12):e28347. Available from: https://dx.plos.org/10.1371/journal.pone.0028347

22. Oguoma V, Ikpeze O. Species composition and abundance of mosquitoes of a tropical irrigation ecosystem. Anim Res Int [Internet] 2009;5(2). Available from:

http://www.ajol.info/index.php/ari/article/view/48748

23. Onyido A, Deezia N, Obiukwu M, Amadi E. Ecology Of Man-Biting Mosquitoes In The Development Site Of Nnamdi Azikiwe University Awka, Anambra State Southeastern Nigeria. Internet J Heal. 2012;9(2):1-7.

24. Anosike JC, Nwoke BE, Ajayi EG, Onwuliri CO, Okoro OU, Oku EE et al. Lymphatic filariasis among the Ezza people of Ebonyi State, eastern Nigeria. Ann Agric Environ Med [Internet] 2005;12(2):181-6. Available from: http://www.ncbi.nlm.nih.gov/pubmed/16457471

25. Service MW. A Guide to Medical Entomology [Internet]. Macmillan; (Macmillan international college editions) 1980.

Available from:https:/books.google.com.ng/books?id=b0YgAQAA MAAJ

26. Zhang J, Lu G, Li J, Kelly P, Li M, Wang J et al. Molecular Detection of Rickettsia felis and Rickettsia bellii in Mosquitoes. Vector-Borne Zoonotic Dis [Internet]. 2019;19(11):802-9. Available from: https://www.liebertpub.com/doi/10.1089/vbz.2019.2456

27. Dieme C, Bechah Y, Socolovschi C, Audoly G, Berenger J-M, Faye $\mathrm{O}$ et al. Transmission potential of Rickettsia felis infection by Anopheles gambiae mosquitoes. Proc Natl Acad Sci [Internet]. 2015;112(26):8088-93. Available from:

http://www.pnas.org/lookup/doi/10.1073/pnas.14138351 12

28. Harbach RE. The Phylogeny and Classification of 
Anopheles. In: Anopheles mosquitoes - New insights into malaria vectors [Internet]. InTech; 2013. Available from: http://www.intechopen.com/books/anophelesmosquitoes-new-insights-into-malaria-vectors/thephylogeny-and-classification-of-anopheles

29. Okogun GRA, Anosike JC, Okere AN, Nwoke BEB. Ecology of mosquitoes of Midwestern Nigeria. J Vector Borne Dis. 2005;42(1):1-8.

30. Hasty JM, Felix GE, Amador M, Barrera R, Santiago GS, Nakasone L et al. Entomological Investigation Detects Dengue Virus Type 1 in Aedes (Stegomyia) albopictus (Skuse) during the 2015-16 Outbreak in Hawaii. Am J Trop Med Hyg [Internet]. 2020;102(4):869-75. Available from: https://ajtmh.org/doi/10.4269/ajtmh.19-0732

31. Gardner CL, Ryman KD. Yellow Fever: A Reemerging Threat. Clin Lab Med [Internet]. 2010 Mar;30(1):237-60. Available from: https://linkinghub.elsevier.com/retrieve/pii/S0272271210 000028n

32. Ozumba NA, Nwosu EO. Some implications of undisposed solid wastes in Enugu urban, Southeastern Nigeria: A preliminary epidemiological perspective study. 27th Annual Conference of the Nigerian Society for Parasitology, 2003;43:48.

33. Tandina F, Doumbo O, Yaro AS, Traoré SF, Parola P, Robert V. Mosquitoes (Diptera: Culicidae) and mosquitoborne diseases in Mali, West Africa. Parasit Vectors [Internet]. 2018;11(1):467. Available from: https://parasitesandvectors.biomedcentral.com/articles/10 .1186/s13071-018-3045-8

34. Kamgang B, Vazeille M, Yougang AP, Tedjou AN, Wilson-Bahun TA, Mousson L et al. Potential of Aedes albopictus and Aedes aegypti (Diptera: Culicidae) to transmit yellow fever virus in urban areas in Central Africa. Emerg Microbes Infect [Internet]. 2019;8(1):1636-41. Available from: https://www.tandfonline.com/doi/full/10.1080/22221751. 2019.1688097

35. Diallo D, Sall AA, Diagne CT, Faye O, Faye O, Ba Y et al. Zika Virus Emergence in Mosquitoes in Southeastern Senegal 2011. Attoui H, editor. PLoS One [Internet] 2014;9(10):e109442. Available from: https://dx.plos.org/10.1371/journal.pone.0109442

\section{Chukwudi Egbuche}

Department of Parasitology and Entomology, Nnamdi Azikiwe University, Awka, Anambra State, Nigeria

\section{Ephraim Ezaka}

a) Department of Parasitology and Entomology, Nnamdi Azikiwe University, Awka, Anambra State, Nigeria

b) Department of Medical laboratory Technology, College of Health Technology, Adamawa State, Nigeria

\section{Chiemelie Okwubanego}

Department of Parasitology and Entomology, Nnamdi Azikiwe University, Awka, Anambra State, Nigeria

\footnotetext{
Ifeanyi Omah

a) Department of Parasitology and Entomology, Nnamdi Azikiwe University, Awka, Anambra State, Nigeria

b) Global Health Policy Unit, University of Edinburgh, Scotland, United Kingdom
}

\section{Victor Odoh}

Department of Parasitology and Entomology, Nnamdi Azikiwe University, Awka, Anambra State, Nigeria

\section{Chidera Obi}

Department of Parasitology and Entomology, Nnamdi Azikiwe University, Awka, Anambra State, Nigeria

\section{Tangkat Dashar}

Department of Medical laboratory Technology, College of Health Technology, Adamawa State, Nigeria

\section{Johnpaul Egbobe \\ a) Department of Parasitology and Entomology, Nnamdi Azikiwe University, Awka, Anambra State, Nigeria \\ b) Department of Public Health, Nanjing Medical University, China}

\section{Sandra Olisakwe}

a) Department of Parasitology and Entomology, Nnamdi Azikiwe University, Awka, Anambra State, Nigeria

b) School of public Health, University of Alabama at Birmingham, USA

\section{Tochukwu Okafor}

Department of Parasitology and Entomology, Nnamdi Azikiwe University, Awka, Anambra State, Nigeria

\section{Ifunanya Nwankwo}

a) Department of Parasitology and Entomology, Nnamdi Azikiwe University, Awka, Anambra State, Nigeria

b) 63 Brigade Medical Center, Asaba, Delta State, Nigeria 